\title{
Synthesis, docking and anticancer activity studies of D-proline-incorporated wainunuamide
}

\author{
M HIMAJA $^{\mathrm{a}, *}$, A RANJITHA ${ }^{\mathrm{a}}$ and SUNIL V MALI ${ }^{\mathrm{b}}$ \\ ${ }^{a}$ School of Advanced Sciences, Pharmaceutical Chemistry Division, VIT University, Vellore 632 014, India \\ ${ }^{b}$ Medicinal Chemistry Division, Piramal Life Science Ltd., Mumbai 400 060, India \\ e-mail: dr_himaja@yahoo.com; jranji16@yahoo.com
}

MS received 17 February 2011; revised 25 July 2011; accepted 23 August 2011

\begin{abstract}
D-proline-incorporated wainunuamide - a cyclic octapeptide was synthesized and characterized by FTIR, ${ }^{1} \mathrm{H}$ and ${ }^{13} \mathrm{C}$ NMR and Mass spectral analysis. Molecular docking studies were carried out for the designed cyclic octapeptide and the results showed greater affinity for HPV18-2IOI receptor (HeLa cancer cell line). The synthesized cyclic octapeptide exhibited potent anticancer activity against HeLa cancer cells.
\end{abstract}

Keywords. Cyclic octapeptide; molecular docking; solution phase synthesis; anticancer activity.

\section{Introduction}

Various active anticancer agents are derived from marine sponges, plants and terrestrial microorganisms. They are rich sources of bioactive cyclic peptides and depsipeptides with unique structures involving a wide variety of unusual amino acids and other building blocks. ${ }^{1-4}$ Many cyclic peptides, isolated from marine sponges, exhibited interesting biological properties including a reverse of multi-drug resistance in tumour cells, ${ }^{5} \mathrm{HIV}$ inhibition, ${ }^{6,7}$ and nematocidal activity. $^{8}$

A cyclic heptapeptide, wainunuamide Cyclo-L-[PhePro-His-Pro-Pro-Gly-Leu], was isolated from a Fijian marine sponge of Stylotella aurantium which showed moderate cytotoxic activity. ${ }^{9}$ The synthetic wainunuamide also exhibited moderate anticancer activity towards HeLa cancer cell lines. ${ }^{10}$ Literature review on cytotoxic cyclic peptides revealed that phakellistatins $^{11}$ and theonellamides ${ }^{12}$ containing D- and/ (or) L- proline units were reported to show potent anticancer activity towards various cancer cells. Based on these results, in order to further enhance the anticancer activity of wainunuamide, a D-proline unit was incorporated into the ring structure of wainunuamide. The cyclic octapeptide Cyclo-D-Pro-(L-Phe-Pro-HisPro-Pro-Gly-Leu) was synthesized by solution phase peptide technique using TBTU [ $O$-(Benzotriazol-1-yl)$N, N, N^{\prime}, N^{\prime}$-tetramethyluronium tetrafluoroborate] as the coupling reagent and triethylamine as the base.

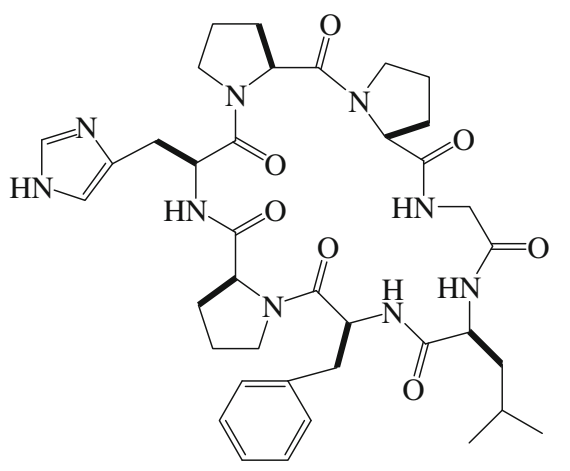

Wainunuamide

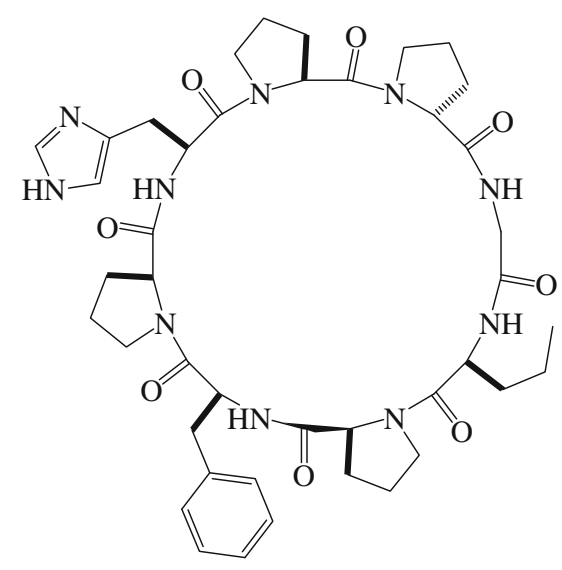

D-Proline incorporated wainunuamide

*For correspondence 


\section{Experimental}

All the reactions requiring anhydrous condition were conducted in flame dried apparatus. Solvents and reagents were purified by standard methods. Organic extracts were dried over anhydrous sodium sulphate. All amino acids and other chemicals were obtained from Spectrochem Private Limited (Mumbai, India). Boc-amino acids and Amino acid methyl ester hydrochlorides were prepared using standard procedures. ${ }^{13}$ Purity of the compounds was checked by pre-coated TLC plate. IR spectra were recorded on Thermo Nicolet FTIR 330 spectrometer using a thinfilm supported on $\mathrm{KBr}$ pellets. ${ }^{1} \mathrm{H}$ and ${ }^{13} \mathrm{C}$ NMR spectra were recorded on Bruker AC NMR spectrometer using $\mathrm{CDCl}_{3}$ as solvent. HRMS Mass spectra were recorded on a Jeol GC Mate. Elemental analysis $(\mathrm{C}, \mathrm{H}$ and N) was carried out using a PERKIN-ELMER 2400 elemental analyzer.

\subsection{Preparation of dipeptides}

Amino acid methyl ester hydrochloride $(10 \mathrm{mmol})$ was dissolved in chloroform $(20 \mathrm{ml})$. To this, triethylamine $(4 \mathrm{ml}, 28.7 \mathrm{mmol})$ was added at $0^{\circ} \mathrm{C}$ and the reaction mixture was stirred for $15 \mathrm{~min}$. Boc-amino acid $(10 \mathrm{mmol})$ in $\mathrm{CHCl}_{3}(20 \mathrm{ml})$ and TBTU $(10 \mathrm{mmol})$ were added and the reaction mixture was stirred for half an hour. After $30 \mathrm{~min}$, the reaction mixture was filtered and the residue was washed with $\mathrm{CHCl}_{3}(30 \mathrm{ml})$ and the washings were added to the filtrate. The filtrate was washed with $5 \% \mathrm{HCl}(20 \mathrm{ml}), 5 \% \mathrm{NaHCO}_{3}(20 \mathrm{ml})$ and saturated $\mathrm{NaCl}(20 \mathrm{ml})$ solutions. The organic layer was filtered, dried over anhydrous $\mathrm{Na}_{2} \mathrm{SO}_{4}$ and evaporated in vacuo to get the synthesized product. The completion of the reaction was monitored by TLC. Boc-Phe-Pro$\mathrm{OMe}$, Boc-His-Pro-OMe and Boc-Pro-Gly-OMe were prepared in the similar manner.

\subsection{Preparation of Boc-Phe-Pro-His-Pro-OMe}

The above tetrapeptide was prepared from the dipeptide Boc-Phe-Pro-OMe and Boc-His-Pro-OMe units after appropriate deprotection ${ }^{14}$ at the required functional groups. The deprotected dipeptide units were coupled using TBTU, $\mathrm{Et}_{3} \mathrm{~N}$ to get the protected tetrapeptide using the procedure similar to that of the dipeptide.

2.2a Tetrapeptide: Boc-Phe-Pro-His-Pro-OMe: Brown sticky semisolid mass, Molecular weight: 610, Molecular Formula: $\mathrm{C}_{31} \mathrm{H}_{42} \mathrm{~N}_{6} \mathrm{O}_{7}$, Yield 79\%; UV $(100 \% \mathrm{MeOH}) \lambda_{\max } 249$; FTIR $\left(\mathrm{KBr} \gamma \mathrm{cm}^{-1}\right): 3227$ (-NH Stretch), 2982 and 2964 (-CH Stretch), 1749 (>CO of ester group), 1681 (>CO Stretch), 1570 (-NH Bend), 1461 (-CH bend). ${ }^{1} \mathrm{H}$ NMR (500 MHz, $\left.\mathrm{CDCl}_{3}\right): \delta 8.0$ 7.5 (m, 7H, Ar-H), 7.2 (s, 1H, -NH of imidazole), 7.0 (s, $1 \mathrm{H},-\mathrm{NH}$ of Phe), 4.8 (t, 2H, $\alpha-\mathrm{CH}$ of Phe and His), $4.2\left(\mathrm{t}, 2 \mathrm{H}, \mathrm{N}-\mathrm{CH}\right.$ of Pro), $4.0\left(\mathrm{~d}, 2 \mathrm{H},-\mathrm{CH}_{2}\right.$ of Phe and His), $3.8\left(\mathrm{~s}, 3 \mathrm{H},-\mathrm{OCH}_{3}\right), 3.2-2.4\left(\mathrm{~m}, 8 \mathrm{H},-\mathrm{CH}_{2}\right.$ of Pro), 3.4-3.3 (t, $4 \mathrm{H}, \mathrm{N}-\mathrm{CH}_{2}$ of Pro), 0.9 (s, $9 \mathrm{H},-\mathrm{CH}_{3}$ of $\mathrm{Boc}$ group). HRMS (EI) m/z: $610.61\left(\mathrm{M}^{+}\right)$. Anal. Calcd. for $\mathrm{C}_{31} \mathrm{H}_{42} \mathrm{~N}_{6} \mathrm{O}_{7}$ : C 60.97, $\mathrm{H}$ 6.93, N 13.76. Found: C 60.89, H 6.80, N 13.66.

\subsection{Preparation of Boc-Pro-Gly-Leu-OMe}

The above tripeptide was prepared from the dipeptide Boc-Pro-Gly-OMe and Leu-OMe units after appropriate deprotection ${ }^{14}$ at the required functional groups. The deprotected dipeptide and Leu-OMe units were coupled using TBTU, $\mathrm{Et}_{3} \mathrm{~N}$ to get the protected tripeptide using the procedure similar to that of the dipeptide.

2.3a Tripeptide: Boc-Pro-Gly-Leu-OMe: Pale Yellowish sticky semisolid mass, Molecular weight: 399, Molecular Formula: $\mathrm{C}_{19} \mathrm{H}_{33} \mathrm{~N}_{3} \mathrm{O}_{6}$, Yield 77\%; UV $(100 \% \mathrm{MeOH}) \lambda_{\max } 232$; FTIR $\left(\mathrm{KBr} \gamma \mathrm{cm}^{-1}\right): 3221$ (-NH Stretch), 2979 and 2960 (-CH Stretch), 1746 (>CO of ester group), 1680 (>CO Stretch), 1576 (-NH Bend), 1466 (-CH bend). ${ }^{1} \mathrm{H}$ NMR $\left(500 \mathrm{MHz} \mathrm{CDCl}_{3}\right)$ :


(t, $1 \mathrm{H},-\mathrm{CH}$ of Leu), 3.6 (s, 3H, $-\mathrm{OCH}_{3}$ of Leu), 3.4$3.2\left(\mathrm{~m}, 2 \mathrm{H},-\mathrm{CH}_{2}\right.$ of Pro), 3.5-3.0 (t, $2 \mathrm{H}, \mathrm{N}-\mathrm{CH}_{2}$ of Pro), 2.9-2.5 (m, 2H, $-\mathrm{CH}_{2}$ of Pro), $1.8\left(\mathrm{~d}, 2 \mathrm{H},-\mathrm{CH}_{2}\right.$ of Leu), 1.7 (m, 1H, -CH of Leu), 1.4 (s, $2 \mathrm{H},-\mathrm{CH}_{2}$ of Gly), 1.0 (s, 6H, $-\mathrm{CH}_{3}$ of Leu), $0.9\left(\mathrm{~s}, 9 \mathrm{H},-\mathrm{CH}_{3}\right.$ of $\mathrm{Boc}$ group). HRMS (EI) m/z: $399.00\left(\mathrm{M}^{+}\right)$. Anal. Calcd. for $\mathrm{C}_{19} \mathrm{H}_{33} \mathrm{~N}_{3} \mathrm{O}_{6}$ : C 57.12, H 8.33, N 10.52. Found: C 57.04, $\mathrm{H} 8.25, \mathrm{~N} 10.42$.

\subsection{Preparation of Boc-D-Pro-Phe-Pro-His-Pro-OMe}

The above pentapeptide was prepared from the tetrapeptide Boc-Phe-Pro-His-Pro-OMe and Boc-DProline units after appropriate deprotection ${ }^{14}$ at the required functional groups. The deprotected tetrapeptide and Boc-D-Proline units were coupled using TBTU, $\mathrm{Et}_{3} \mathrm{~N}$ to get the protected pentapeptide using the procedure similar to that of dipeptide.

\subsection{Preparation of linear octapeptide -}

Boc-D-Pro-L-(Phe-Pro-His-Pro-Pro-Gly-Leu-OMe)

The Boc-group of the tripeptide (Boc-Pro-GlyLeu-OMe) was removed and the ester group of the 
pentapeptide (Boc-D-Pro-Phe-Pro-His-Pro-OMe) was deprotected. Both the deprotected units were coupled to get the linear octapeptide- Cyclo D-Pro-L(Phe-Pro-His-Pro-Pro-Gly-Leu).

\subsection{Preparation of Cyclo-D-Pro-L-(Phe-Pro-His- Pro-Pro-Gly-Leu)}

The cyclisation of the linear octapeptide unit was carried out by $p$-nitrophenyl ester method of Bodanszky ${ }^{15}$ with certain modifications. The ester group of the linear segment was removed with $\mathrm{LiOH}$ and the p-nitrophenyl ester group was introduced using the following procedure:

To the solution of $2.2 \mathrm{mmol}$ of Boc-peptide carboxylic acid in $15 \mathrm{ml}$ of $\mathrm{CHCl}_{3}$ was added and $0.31 \mathrm{ml}$ $(2.2 \mathrm{mmol})$ of triethylamine. After cooling in an ice bath, $0.44 \mathrm{~g}(2.2 \mathrm{mmol})$ of $p$-nitrophenol ${ }^{16}$ was added and stirred for $12 \mathrm{~h}$ at room temperature. The reaction mixture was filtered and the filtrate was washed with $10 \% \quad \mathrm{NaHCO}_{3}(5 \mathrm{ml})$ solution until excess of $p$-nitrophenol was removed and finally washed with 5\% $\mathrm{HCl}(5 \mathrm{ml})$ to get Boc-Peptide-pnp-ester.

To the above Boc-peptide-pnp-ester $(2 \mathrm{mmol})$ in $\mathrm{CHCl}_{3}(10 \mathrm{ml}), \mathrm{CF}_{3} \mathrm{COOH}(2 \mathrm{mmol})$ was added, stirred for $1 \mathrm{~h}$ at room temperature and washed with $10 \% \mathrm{NaHCO}_{3}$ solution. The organic layer was dried over anhydrous $\mathrm{Na}_{2} \mathrm{SO}_{4}$. To the Boc-deprotected peptide-pnp-ester $(1.5 \mathrm{mmol})$ in $\mathrm{CHCl}_{3}(10 \mathrm{ml})$, TBTU $(1.5 \mathrm{mmol})$, triethyl amine $(1.5 \mathrm{mmol})$ was added and stirred for half an hour. The reaction mixture was washed with $10 \% \mathrm{NaHCO}_{3}$ until the byproduct $p$-nitrophenol was removed completely and finally washed with $5 \% \mathrm{HCl}(5 \mathrm{ml})$ dried and evaporated in vacuo to get the cyclised product Cyclo-D-Pro-L(Phe-Pro-His-Pro-Pro-Gly-Leu).

2.6a Cyclic octapeptide: Cyclo-D-Pro-L-(Phe-ProHis-Pro-Pro-Gly-Leu): Yellowish semisolid mass, Molecular weight: 843, Molecular Formula: $\mathrm{C}_{43} \mathrm{H}_{58} \mathrm{O}_{8} \mathrm{~N}_{10}$, Yield $75 \%$; UV $(100 \% \mathrm{MeOH}) \lambda_{\max }$ 300; FTIR (KBr $\left.\gamma \mathrm{cm}^{-1}\right)$ : 3331 (-NH Stretch), 2989 and 2964 (-CH Stretch), 1716 (CO Stretch), 1569 (-NH Bend), 1458 (-CH bend). ${ }^{1} \mathrm{H}$ NMR (500 $\left.\mathrm{MHz} \mathrm{CDCl}_{3}\right)$ : $\delta$ 7.8-7.1 (m, 7H, Ar-H), 7.3 (s, 1H, -NH of imidazole), 7.2-6.8 (s, 3H, -NH), 4.7 (t, 2H, - $\mathrm{CH}$ of Phe and His), $4.3\left(\mathrm{t}, 4 \mathrm{H}, \mathrm{N}-\mathrm{CH}\right.$ of Pro), $4.0\left(\mathrm{~d}, 4 \mathrm{H},-\mathrm{CH}_{2}\right.$ of Phe and His), 3.0-2.7 (t, $8 \mathrm{H}, \mathrm{N}-\mathrm{CH}_{2}$ of Pro), 3.8 (t, $1 \mathrm{H},-\mathrm{CH}$ of Leu), $3.5-3.2\left(\mathrm{~m}, 16 \mathrm{H},-\mathrm{CH}_{2}\right.$ of Pro), $1.8(\mathrm{~d}, 2 \mathrm{H}$, $-\mathrm{CH}_{2}$ of Leu), $1.7(\mathrm{~m}, 1 \mathrm{H},-\mathrm{CH}$ of Leu), $1.4(\mathrm{~s}, 2 \mathrm{H}$, $-\mathrm{CH}_{2}$ of Gly), 1.0 (s, 6H, $-\mathrm{CH}_{3}$ of Leu). ${ }^{13} \mathrm{C}$ NMR $\left(125 \mathrm{MHz} \mathrm{CDCl}_{3}\right): \delta 168.9$ (>CO of Phe), 170.5 (>CO of Gly), 171.3 ( $>\mathrm{CO}$ of His), 172.1 ( $>\mathrm{CO}$ of Pro), 173.8 ( $>\mathrm{CO}$ of Leu), 174.7 ( $>\mathrm{CO}$ of Pro), 175.2 (>CO of Pro), $\delta 119.2,127.4,128.4,130.3,130.5,134.9$, 138.7, (Ar-C of Phe and His), $\delta 60.6$ (Pro $\left.\alpha-\mathrm{CH}_{2}\right), 61.4$ (Pro $\alpha-\mathrm{CH}_{2}$ ), 62.6 (Pro $\alpha-\mathrm{CH}_{2}$ ), 64.3s (Pro $\alpha-\mathrm{CH}_{2}$ ), $\delta 53.5$ (His $\alpha-\mathrm{CH}), \delta 50.7$ ( $\alpha-\mathrm{CH}$ of Phe), 44.8 (Gly $\left.\alpha-\mathrm{CH}_{2}\right), \delta 41.5\left(\mathrm{Leu}-\mathrm{CH}_{2}\right), \delta 45.1$ (Pro $\left.\delta-\mathrm{CH}\right), 46.7$ (Pro $\delta$-CH), 46.9 (Pro $\delta$-CH), 47.2 (Pro $\delta$-CH), $\delta 37.7$ $\left(\alpha-\mathrm{CH}_{2}\right.$ of Phe), 28.7 (Pro $\beta-\mathrm{CH}_{2}$ ), $\delta 29.1$ (Pro $\beta$ $\mathrm{CH}_{2}$ ), 32.4 (Pro $\beta-\mathrm{CH}_{2}$ ), 32.7 (Pro $\beta-\mathrm{CH}_{2}$ ), $\delta 28.7$ (His $\left.\beta-\mathrm{CH}_{2}\right) \delta 22.7\left(\right.$ Pro $\gamma-\mathrm{CH}_{2}$ ), $24.3\left(\right.$ Pro $\left.\gamma-\mathrm{CH}_{2}\right), 24.8$ (Pro $\gamma-\mathrm{CH}_{2}$ ), $25.2\left(\operatorname{Pro} \gamma-\mathrm{CH}_{2}\right.$ ), $\delta 20.5$ and 20.8 (Leu $\left.\alpha 2-\mathrm{CH}_{3}\right)$. HRMS (EI) m/z: $843.17\left(\mathrm{M}^{+}\right)$. Anal. Calcd. for $\mathrm{C}_{43} \mathrm{H}_{58} \mathrm{O}_{8} \mathrm{~N}_{10}$ : C 61.27, H 6.93, N 16.62. Found: C 61.19, H 6.79, N 16.52.

\subsection{Molecular docking}

We have used the following bioinformatics tools; biological databases like PDB (Protein Data Bank), ${ }^{17,18}$ Swiss-PDB Viewer Version ${ }^{19} 3.7$ and docking software - Hex Version ${ }^{20} 5.1$ ACD ChemSketch (ACD/ Labs, www.acdlabs.com. The Protein Data Bank (PDB) is the single worldwide archive of structural data of biological macromolecules, established in Brookhaven National Laboratories. ${ }^{21}$ Computer aided drug design methods are heavily dependent on bioinformatics tools, applications and databases. ${ }^{22}$ The structure of 2IOI (HPV - human papillomavirus) receptor molecule (figure 1) was retrieved from protein data bank (PDB Code: 2IOI).

Using ChemSketch the structure of the cyclic octapeptide was sketched. The docking analysis of the cyclic octapeptide with 2IOI was carried by HEX docking software. Docking allows the scientist to virtually screen a database of compounds and predict the strongest binders based on the various scoring functions. It explores ways in which two molecules, such as ligand and 2IOI receptor fit together and dock to each other. The cyclic octapeptide molecules binding to a 2IOI receptor, inhibit its function, and thus act as an anticancer drug. The collection of drug and receptor complex was identified via docking and their relative stabilities were evaluated using molecular dynamics and their binding affinities, using free energy simulations. Based on the total energy values, the anticancer activity of the compound was identified.

\subsection{Anticancer activity}

MTT [3-(4, 5-Dimethylthiazole-2-yl)-2,5diphenyltetrazoliumbromide] assay ${ }^{23,24}$ - (Human breast adenocarcinoma cell line) were obtained from ATCC and 


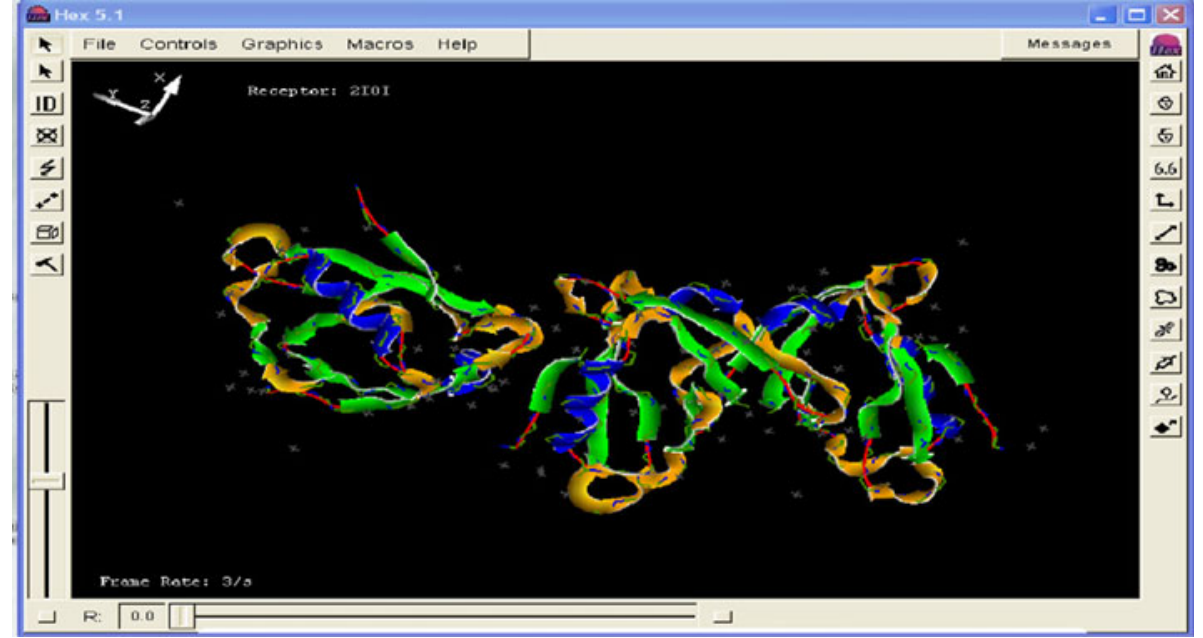

Figure 1. Structure of HPV18-2IOI receptor.
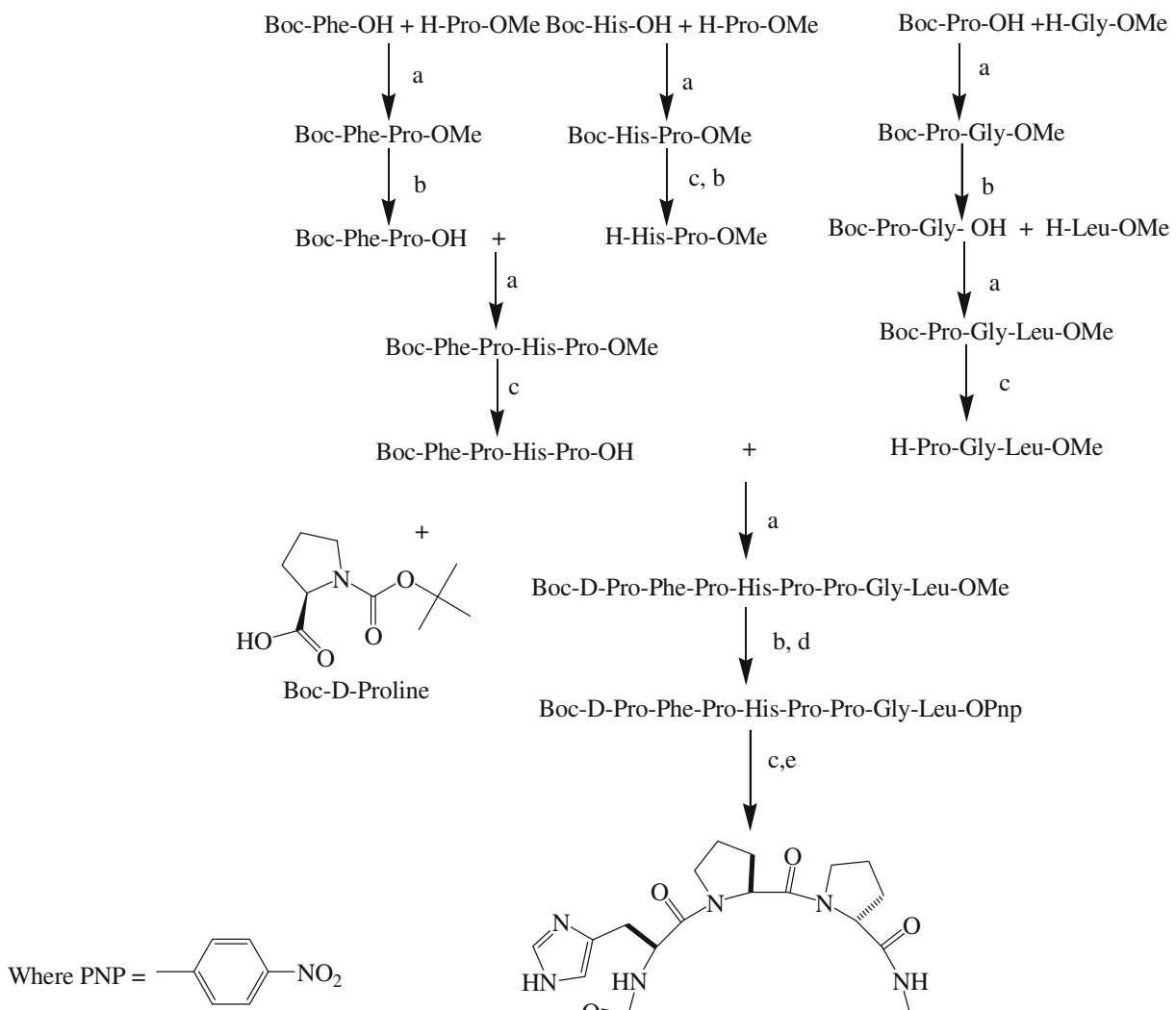

$\mathrm{a}=\mathrm{CHCl}_{3}, \mathrm{TBTU}, \mathrm{Et}_{3} \mathrm{~N}, 1 / 2 \mathrm{hr}, \mathrm{RT}$, $\mathrm{b}=$ THF: $\mathrm{H}_{2} \mathrm{O}$ (1:1), LiOH, 1h, RT, $\mathrm{c}=\mathrm{CF}_{3} \mathrm{COOH} / \mathrm{CHCl}_{3}, 1 \mathrm{~h}, \mathrm{RT}$ $\mathrm{d}=$ p-nitrophenol, $\mathrm{CHCl}_{3}, 12 \mathrm{~h}, \mathrm{RT}$ $\mathrm{e}=\mathrm{CHCl}_{3}, \mathrm{Et}_{3} \mathrm{~N}, \mathrm{TBTU}, 1 / 2 \mathrm{hr}, \mathrm{RT}$

TBTU = 2-(1H-benzotriazole-1-yl)-1, 1, 3, 3 tetramethyluronium tetrafluoroborate

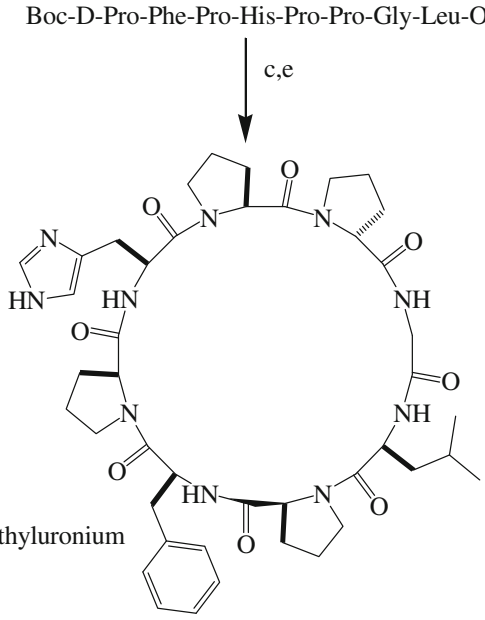

\section{Cyclic octapeptide Reaction Scheme-1}

Scheme 1. Cyclic octapeptide reaction. 
Table 1. Docking results of cyclic octapeptide with different anticancer receptors.

\begin{tabular}{lll}
\hline S. No & (PDB Code) & $\begin{array}{l}\text { Cyclic octapeptide } \\
\text { E total }(\mathrm{kJ} / \mathrm{mol})\end{array}$ \\
\hline 1 & 1ZZF & -119.14 \\
2 & $1 \mathrm{JLM}$ & -108.96 \\
3 & $1 \mathrm{IDO}$ & -73.14 \\
4 & $1 \mathrm{R} 8 \mathrm{P}$ & -68.17 \\
5 & 2IOI & -160.11 \\
\hline
\end{tabular}

Standard anticancer drug - Camptothecin -141.65 $(\mathrm{kJ} / \mathrm{mol})$.

maintained in DMEM (Hi-Media Laboratories Pvt. Ltd, Mumbai, India) supplemented with $10 \%$ heatinactivated FBS (v/v), streptomycin $(100 \mu \mathrm{g} / \mathrm{ml})$ and penicillin $(100 \mu \mathrm{g} / \mathrm{ml})$. The cell line was maintained at $37^{\circ} \mathrm{C}$ with $5 \%$ carbon dioxide in $\mathrm{CO}_{2}$ incubator. The MTT cell proliferation assay was used to evaluate the anticancer activity of D-Proline incorporated wainunuamide using the Cell Quantification MTT cell viability assay kit (Bioassay Systems). The optical density was measured at $570 \mathrm{~nm}$ for each well on the absorbance plate reader. Trypan blue dye exclusion assay was also used to count the number of viable and nonviable HeLa cancer cells in the culture medium after drug treatment. Treatment with 5-FU at the same concentration served as positive control.

\section{Results and discussion}

In order to carry out the synthesis, the wainunuamide was disconnected into one tripeptide and tetrapeptide units, Boc-Pro-Gly-Leu-OMe and Boc-Phe-Pro-HisPro-OMe. Both tripeptide and tetrapeptide units were synthesized by standard method using TBTU as coupling reagent. ${ }^{25}$ The synthesized tetrapeptide was treated with Boc-D-Proline to get pentapeptide unit. The tripeptide and pentapeptide units containing Bocand ester groups were properly deprotected and coupled together to get the linear octapeptide. Finally the linear octapeptide was cyclised using $p$-nitrophenyl ester method (scheme 1).

FTIR spectrum of cyclic octapeptide showed characteristic medium to strong bands corresponding to the carbonyl stretching at $1716 \mathrm{~cm}^{-1}$ and $\mathrm{NH}$ bending at $1569 \mathrm{~cm}^{-1}$, confirmed the coupling reaction of the cyclic octapeptide. ${ }^{1} \mathrm{H}$ and ${ }^{13} \mathrm{C}$ NMR spectrum of the synthesized cyclic octapeptide showed a peak corresponds to the peptide clearly confirm the coupling of amino acids and peptides. The mass spectral data confirm a stable molecular ion peak $\left[843.17-\mathrm{M}^{+}\right.$] for the synthesized compound. Based on the above mentioned spectral datas, the structure of the cyclic octapeptide was confirmed. The spectral data values for the synthesized cyclic octapeptide are shown in the experimental section.

Docking studies have been carried out using Hex software tool. The designed cyclic octapeptide were docked with different target cancer receptors collected from protein database bank, out of all receptors HPV182IOI receptor had shown good binding interaction with the (ligand) cyclic octapeptide. The results were shown in table 1.

The D-Proline incorporated wainunuamide had shown good docking score [-160.11 kJ/mol] (figure 2) with HPV18-2IOI proteins. The docking result was

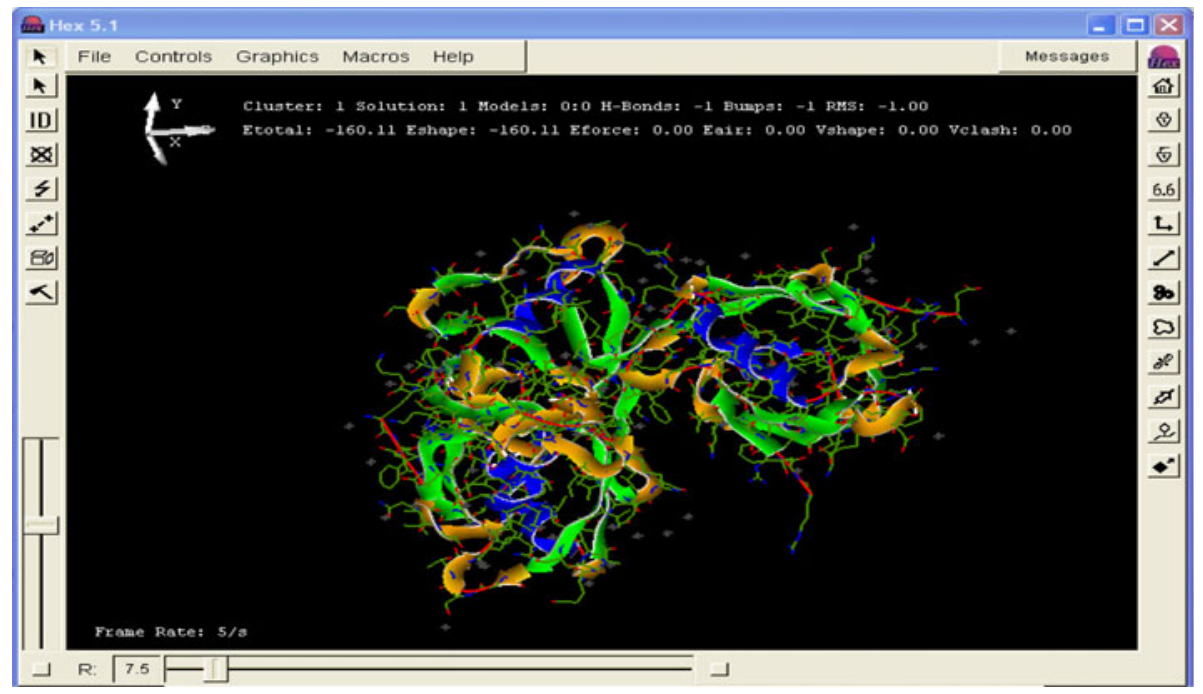

Figure 2. Interaction and binding energy of cyclic octapeptide with 2IOI receptor. 


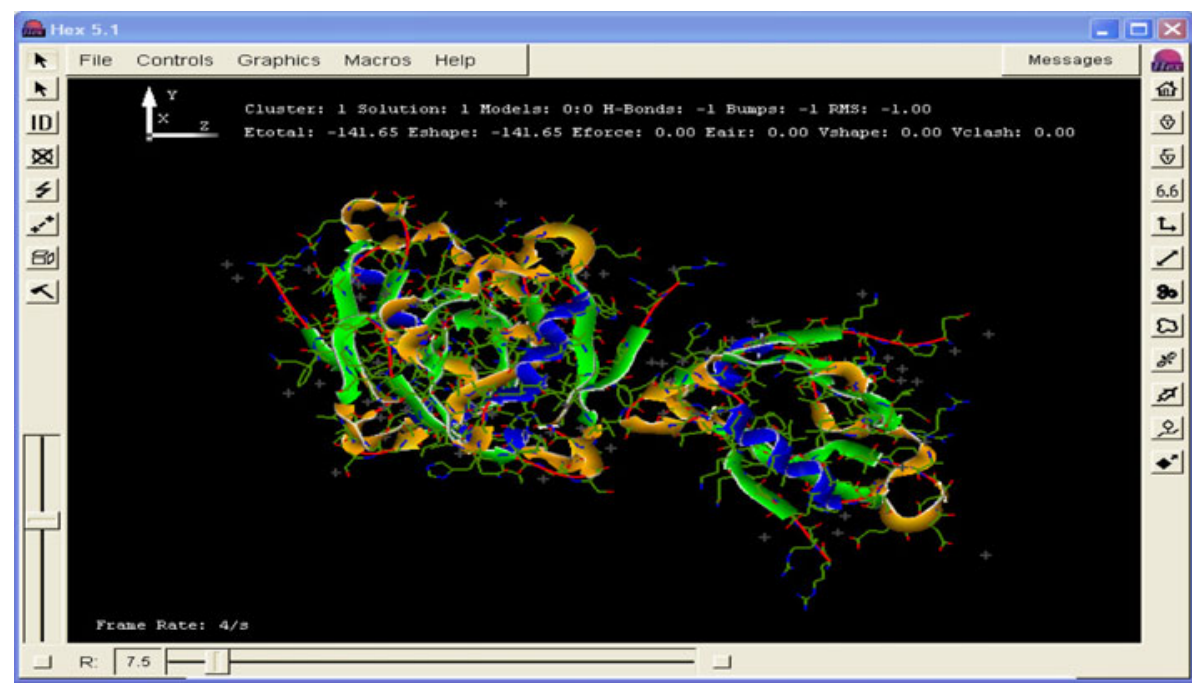

Figure 3. Interaction and binding energy of camptothecin with 2IOI receptor.

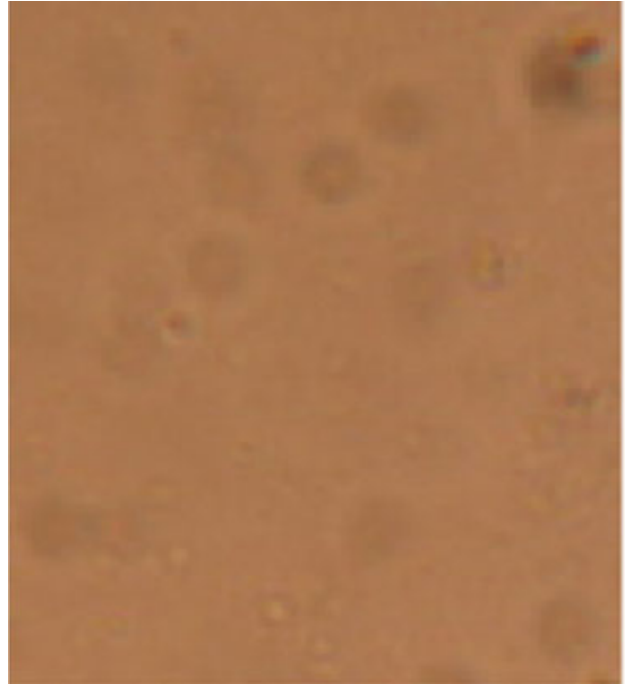

(a)

Control

Figure 4. Representative phase micrograph of Hela cancer cell lines of control group and of those treated with the one studied preparations (a) Control cells, untreated Hela cells, (100\% viability); (b) Hela cells treated with cyclic octapeptide (1) at $50 \mu \mathrm{g} / \mathrm{ml}(27 \%$ viability).

(b) compared with that of standard anticancer drug Camptothecin [-141.65 kJ/mol] (figure 3). Based on the docking score, the synthesized compound was evaluated for the anticancer activity towards Hela cancer cell line.

The effects of D-Proline incorporated cyclic octapeptide on the growth of HeLa cancer cells were tested under in vitro conditions using different concentrations $(5,15,25$ and $50 \mu \mathrm{g} / \mathrm{ml})$ and the cell survival after $48 \mathrm{~h}$ was shown in the figure 4 . The D-Proline incorporated wainunuamide inhibited the growth of $\mathrm{HeLa}$ cancer cells and the results are shown in the table 2 . The results

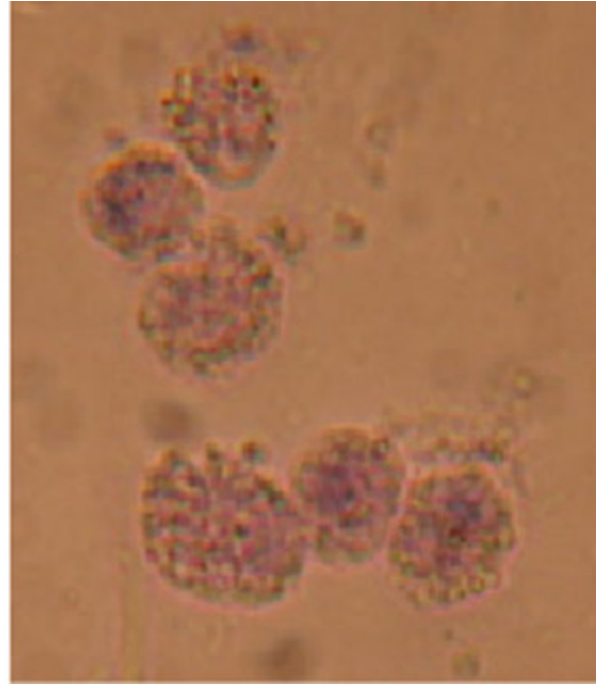

Treated of D-Proline-incorporated wainunuamide were compared with synthetic wainunuamide. The D-proline unit containing wainunuamide showed potent anticancer activity than that of synthetic wainunuamide. The $\mathrm{IC}_{50}$ values were calculated to be $31.75 \mu \mathrm{g} / \mathrm{ml}$ for D-Proline incorporated wainunuamide and $20.58 \mu \mathrm{g} / \mathrm{ml}$ for synthetic wainunuamide. After 96 h, D-Prolineincorporated wainunuamide $(50 \mu \mathrm{g} / \mathrm{ml})$ exhibited potent anticancer activity $27 \%$ ( $73 \%$ cell death) on HeLa cancer cells, but the synthetic wainunuamide had shown $53 \%$ cell viability (47\% cell death) on HeLa cancer cells. 
Table 2. Effect of cyclic octapeptide on HeLa cancer cell line.

Anticancer activity of D-Proline incorporated cyclic heptapeptide (wainunuamide) on HeLa cell lines after $48 \mathrm{~h}_{\text {treatment }}{ }^{\mathrm{a}}$

\begin{tabular}{lcc}
\hline Compound & Percentage of viable cells \\
& Control & Treated \\
Cyclic octapeptide & 100 & 27 \\
\hline
\end{tabular}

${ }^{a}$ Values are mean of the three experiments. The viable HeLa cells were calculated after $48 \mathrm{~h}$ of cyclic octapeptide treatment and strained with trypan blue dye exclusion test

\section{Conclusion}

In conclusion, TBTU was found to be effective coupling reagent giving high yields and reduced reaction time $(30 \mathrm{~min})$ as compared to DCC $(24 \mathrm{~h})$ and EDC (12 h). Molecular docking studies concluded that the designed cyclic octapeptide showed greater affinity towards HPV18-2IOI target protein for cancer. Based on the docking results, the synthesized cyclic octapeptide was evaluated for the anticancer activity and the compound showed potent anticancer activity as compared to that of the parent cyclic heptapeptide wainunuamide.

\section{Acknowledgements}

The authors are thankful to Vellore Institute of Technology (VIT) University for providing the chemicals and laboratory facilities. The authors are thankful to Indian Institute of Technology (IIT) Madras for providing the spectral data.

\section{References}

1. Faulkner D 2002 J. Nat. Prod. Rep. 191

2. Schemjakin M M 1960 Angew. Chem. 72342

3. Hill R A 2005 Annu. Rep. Prog. Chem. Sect. B 101124
4. Aoki S, Cao L, Matsui K, Rachmat R, Akiyama S, Kobayashi M 2004 Tetrahedron 607053

5. Oku N, Gustafson K R, Cartner L K, Wilson J A, Shigematsu N, Hess S, Pannell L K, Boyd M R, McMahon J B 2004 J. Nat. Prod. 671407

6. Mitchell S S, Faulkner D J, Rubins K, Bushman F D 2000 J. Nat. Prod. 63279

7. Capon R J, Ford J, Lacey E, Gill J H, Heiland K, Friedel T 2002 J. Nat. Prod. 6558

8. He Y b, Huang Z, Raynor K, Reisine T, Goodman M 1993 J. Am. Chem. Soc. 1158066

9. Jioji Tabudravu, Linda A Morris, J Jantina Kettenes-van den Bosch and Marcel Jaspars 2001 Tetrahedron Lett. 42 9273

10. Himaja M, Ranjitha J, and Mali S V 2009 Indian Drugs 9682

11. Pettit G R, Cichacz Z, Barkoczy J, Dorsaz A C, Herald D, Williams M D, Doubek D L, Schmidt J M, Tackett L P and Brune D C 1993 J. Nat. Prod. 56260

12. Matsunaga S, Fusetani N, Hashimoto K, Walchli M, 1989 J. Am. Chem. Soc. 1112582

13. Bodanszky M, Bodanszky A 1984 Practice of peptide synthesis. 1st Ed. (New York: Springer-Verlag) vol. 143, p. 91

14. Belagali S L, Harish Kumar K, Poojary B, Himaja M 1998 Acta Chim. Turcica. 2659

15. Bodanszky M, Bodanszky A 1984 Practice of peptide synthesis. 1st Ed. (New York: Springer-Verlag) vol. 131, p. 91

16. Paul Gagnon, Xicai Huang, Eric Therrien and Jeffrey W Keillor 2002 Tetrahedron Lett. $\mathbf{4 3} 7717$

17. Berman HM 2008 Acta Crystallographica 6488

18. Duhovny D S, Inbar Y, Nussinov R, Wolfson H J 2005 Nucleic Acids Res. 33363

19. Guex N and Peitsch MC 1997 Electrophoresis 182714

20. Fei Liu and Bai-Shan Fang 2007 Chinese J. Biotechnol. 23(1) 133

21. Berman H M, Westbrook J, Feng Z, Gilliland G, Bhat T N, Weissig H, Shindyalov I N and Bourne P E 2000 Nucleic Acids Res. 28235

22. Ambesi-Impiombato A, Bernardo D 2006 Curr. Bioinformat. 13

23. Carnichael J, DeGraff W G, Gazdar A F Minna J D, Mitchell J B 1987 Cancer Res. 47936

24. Mosmann T 1983 J. Immunol. Meth. 6555

25. Andrey S Ivanov, Anna A Zhalnina, Sergey V Shishkov 2009 Tetrahedron 65(34) 7105 